Original article

\title{
Supplementation of Nodulisporium sp. KT29 induced by Vibrio harveyi as an immunostimulant for controlling vibriosis in vannamei white shrimp under marine culture system
}

\section{Suplementasi Nodulisporium sp. KT29 yang diinduksi Vibrio harveyi sebagai imunostimulan terhadap pengendalian vibriosis pada udang vaname yang dibudidayakan di laut}

\author{
Dinamella Wahjuningrum $^{1 *}$, Teuku Reza Efianda ${ }^{4}$, Kustiariyah Tarman $^{2,3}$, \\ Munti Yuhana ${ }^{1}$, Irzal Effendi ${ }^{1,3}$, Fazril Saputra ${ }^{5}$ \\ ${ }^{1}$ Department of Aquaculture, Faculty of Fisheries and Marine Science, IPB University \\ ${ }^{2}$ Department of Aquatic Products Technology, Faculty of Fisheries and Marine Science, IPB University \\ ${ }^{3}$ Center of Coastal and Marine Resources Studies (CCMRS), IPB University \\ ${ }^{4}$ Department of Fisheries, Politeknik Indonesia Venezuela, Aceh Besar \\ ${ }^{5}$ Department of Aquaculture, Faculty of Fisheries and Marine Science, Teuku Umar University, West Aceh \\ *Corresponding author : dinamella@yahoo.com
}

(Received January 29, 2018; Accepted October 7, 2019)

\begin{abstract}
The purpose of this study is to evaluate the effectiveness of Nodulisporium sp. KT29 supplementation with various Vibrio harveyi induction in feed against vibriosis in vannamei white shrimp. The study design included KP (positive control without supplementation Nodulisporium sp. KT29 and infected with $V$. harveyi), KN (negative controls without Nodulisporium sp. KT29 and infected with physiological solution), NT (treatment of supplementation Nodulisporium sp KT29 $20 \mathrm{~mL} / \mathrm{kg}$ and infected with $V$. harveyi), NM (treatment of supplementation test Nodulisporium sp. KT29 induction of $V$. harveyi dead cell $20 \mathrm{~mL} / \mathrm{kg}$ and infected $V$. harveyi), NH (treatment of supplementation Nodulisporium sp. KT29 induction of $V$. harveyi live cell $20 \mathrm{~mL} / \mathrm{kg}$ and infected with $V$. harveyi). The study parameters included inhibition zone, resistance, immune responses, and hemolim glucose. The results showed Nodulisporium sp. KT29 with induction treatment raised antibacterial activity with best treatment of NM and $\mathrm{NH}(\mathrm{P}<0.05)$. The results of $V$. harveyi infection resistance presented NM treatment of $20 \mathrm{~mL} / \mathrm{kg}$ increase survival in vannamei shrimp reached $72.2 \%(\mathrm{P}<0.05)$. In addition, the same treatment increase the immune response activity and decrease the activity of hemolim glucose. It could be concluded that providing NM $20 \mathrm{~mL}$ treatment boosted the resistance and the immune system in vaname shrimp to control vibriosis reared at the sea.
\end{abstract}

Keywords: antibacterial, $\beta$-glucan, induced, Nodulisporium sp. KT29, Vibrio harveyi

\begin{abstract}
ABSTRAK
Tujuan penelitian yaitu mengevaluasi efektivitas suplementasi Nodulisporium sp. KT29 dengan berbagai perlakuan induksi Vibrio harveyi dalam pakan terhadap pengendalian vibriosis pada udang vaname yang dibudidayakan di laut. Rancangan penelitian meliputi KP (kontrol positif tanpa suplementasi Nodulisporium sp. KT29 dan diinfeksi $V$. harveyi), KN (kontrol negatif tanpa Nodulisporium sp. KT29 dan diinfeksi larutan fisiologis), NT (perlakuan uji suplementasi Nodulisporium sp. KT29 $20 \mathrm{~mL} / \mathrm{kg}$ dan diinfeksi $V$. harveyi), NM (perlakuan uji suplementasi Nodulisporium sp. KT29 diinduksi sel mati $V$. harveyi $20 \mathrm{~mL} / \mathrm{kg}$ dan diinfeksi $V$. harveyi), NH (perlakuan uji suplementasi Nodulisporium sp. KT29 induksi sel hidup V. harveyi $20 \mathrm{~mL} / \mathrm{kg}$ dan diinfeksi V. harveyi). Parameter penelitian meliputi zona hambat, resistensi, respons imun, dan glukosa hemolim. Hasil penelitian menunjukkan Nodulisporium sp. KT29 dengan perlakuan induksi dapat meningkatkan aktivitas antibakteri dengan perlakuan terbaik NM dan NH (P<0.05). Hasil pengamatan resistensi infeksi V. harveyi menunjukkan perlakuan NM $20 \mathrm{~mL} /$ $\mathrm{kg}$ dapat meningkatkan kelangsungan hidup pada udang vaname mencapai $72.2 \%(\mathrm{P}<0.05)$. Perlakuan yang sama juga meningkatkan respons imun dan menurunkan aktivitas glukosa hemolim. Disimpulkan bahwa pemberian NM 20 mL dapat meningkatkan resistensi dan sistem imun udang vaname terhadap pengendalian vibriosis di laut.
\end{abstract}

Kata kunci : antibakteri, $\beta$-glucan, induksi, Nodulisporium sp. KT29, Vibrio harveyi, 


\section{INTRODUCTION}

The white shrimp Litopenaeus vannamei is a major commodity in Indonesia. The production of white shrimp is increasing each year to fulfill market demand. Several issues during white shrimp rearing are required to be eliminated, such as water quality, nutrition, biosecurity, and disease (Ekasari et al., 2016). The disease control becomes main priority in raising white shrimp production. One of the most frequently disease which attacked white shrimp is vibriosis caused by Vibrio harveyi (Widanarni et al., 2012). The most common ways to control the disease are using antibiotics (Defoirdt et al., 2011), SPF juvenile selection (Lightner, 2005), using normal ingredients, and sinbiotics which acts as immunostimulant (Sirirustananun et al., 2011; Zubaidah et al., 2015). The antibiotics application was prohibited nowadays because of the food security issue. It is confirmed that the requirement of natural ingredients to control disease outbreak is urgently needed. Therefore, immunostimulant is one of the environmental friendly alternative in boosting immune system towards bacteria.

Nodulisporium sp. KT29 is endophyte mold isolated from red algae Euchema edule. It contains antibacterial and antioxidant compounds, such as $\beta$-glukan, saponin, polyphenol, and phytosterol (Tarman et al., 2011). The application of Nodulisporium sp. KT29 as aimmunostimulant was known to enhance shrimp immune system towards vibriosis (Wahjuningrum et al., 2016). The high dosage utilization of Nodulisporium sp. KT29 is considered as high cost production, so that further evaluations were required to reduse production cost.

The utilization of natural ingredients to increase the eco-firendly active ingredients can be done using bacteria induction, salinity, pressure, light, and temperature (Tarman et al., 2011). The bacteria induction method was applied in this study with natural ingredients Nodulisporium sp. KT29. The enhancing of active ingredients in Nodulisporium sp. KT29 was conducted using Vibrio harveyi induction to produce secondary metabolite. Mearns-Spragg et al. (1998) reported that the addition of pathogenic bacteria, such as Escherisia coli which collectively cultured with Fucus vesiculosus algae was able to boost secondary metabolite, such as saponin. The secondary metabolite itself was used to induce shrimp immune system towards vibriosis. This study aimed to evaluate the application of
Nodulisporium sp. KT29 metabolite induced by Vibrio harveyi to elevate the resistance and immune system of white shrimp towards vibriosis.

\section{MATERIALS AND METHODS}

\section{Location}

This study was conducted in August 2016 until March 2017. It took place in Fish Health Laboratory, Aquaculture Department, Microbiology of Aquatic Products Laboratory, Aquatic Product Technology Department, Faculty of Fisheries and Marine Sciences, IPB University and sea farming PKSPL LPPM-IPB, Semak Daun, Thousands Island, Jakarta.

\section{Experimental materials}

The experimental materials were white shrimp $\mathrm{PL}_{10}$, Nodulisporium sp. KT29 isolate, and Vibrio harveyi. The average weight and length of white shrimp was $0.014 \pm 0.01 \mathrm{~g}$ and $0.8 \pm 0.01 \mathrm{~cm}$, respectively. The post larvae were produced by PT. Suri Tani Pemuka, Anyer, Banten, Indonesia. The Nodulisporium sp. KT29 isolate was got from Microbiology of Aquatic Products Laboratory, Aquatic Product Technology Department, while the Vibrio harveyi isolate was picked from Fish Health Laboratory, Aquaculture Department, IPB University.

\section{Nodulisporium sp. KT29 cultivation}

Nodulisporium sp. KT29 cultivation was directed using Tarman et al. (2011) method). The method was begun with the Nodulisporium sp. KT29 isolate rejuvenation in potato dextrose agar (PDA) for seven days in $28-30^{\circ} \mathrm{C}$. The result of preculture was used in three different treatments, $V$. harveyi dead cell induction of Nodulisporium sp. KT29 (NM), V. harveyi active cell induction of Nodulisporium sp. KT29 (NH), and without induction (NT). $V$. harveyi suspension was prepared in $300 \mathrm{~mL}$ of sea water complete (SWC) broth and incubated in waterbath shaker for 18 hours in $28-30^{\circ} \mathrm{C}$ with $160 \mathrm{rpm}$. The NM treatment was prepared using autoclave in $121^{\circ} \mathrm{C}$ for 30 minutes before mass culture.

The result of Nodulisporium sp. KT29 preculture was collected separatedly $12.5 \mathrm{~mL}$ (5\%) and mixed with $V$. harveyi dead cell induction (NM) $12.5 \mathrm{~mL}(5 \%), V$. harveyi active cell induction (NH) $12.5 \mathrm{~mL}(5 \%)$, and no cell induction treatment (NT). The mass cultured was conducted in $250 \mathrm{~mL}$ of PDB for 14 days using shaker with $120 \mathrm{rpm}$ and $28-30^{\circ} \mathrm{C}$. 
The collection was done at day 15 using whatman filter paper (mesh size $0.45 \mu \mathrm{m}$ ) and then the Nodulisporium sp. KT29 sample was evaporated (in $40^{\circ} \mathrm{C}$ ) to separate water content and a $50 \mathrm{~mL}$ from $250 \mathrm{~mL}$ Nodulisporium sp. KT29 metabolite was reserved. As many of 20 $\mathrm{mL}$ of the sample was used in the treatments (NT, $\mathrm{NM}$, and $\mathrm{NH}$ ).

The preparation of antibacterial testing used maceration method to obtain the Nodulisporium sp. KT29 metabolite. The maceration method used EtOAc (ethyl acetate) with ratio 1:2 $(100 \mathrm{~mL}$ of Nodulisporium sp. KT29 : $200 \mathrm{~mL}$ of EtOAc) for $3 \times 24$ hours in shaking condition (120 rpm), then evaporated (in $40^{\circ} \mathrm{C}$ ) and reserved $1 \mathrm{~mL}$ ).

\section{The tested feed preparation}

This study used commercial feed. The basal feed (positive and negative control feed) was repelleted with $0.1 \%(1 \mathrm{~g} / \mathrm{kg})$ of vitamin $\mathrm{C}$ addition and carboxyl methyl cellulose (CMC) as binder $(3 \%, 30 \mathrm{~g} / \mathrm{kg})$. The tested feed was also repelleted with Nodulisporium sp. KT29 metabolite addition based on the treatment, i.e NT (Nodulisporium sp. KT29 without $V$. harveyi cell induction), NM (Nodulisporium sp. KT29 with $5 \%$ of $20 \mathrm{~mL} / \mathrm{kg}$ of $V$. harveyi dead cell induction), and $\mathrm{NH}$ (Nodulisporium sp. KT29 with $5 \%$ of $20 \mathrm{~mL} / \mathrm{kg}$ of $V$. harveyi live cell induction). After being extruded, the feed was crumbled into smaller pieces (crumbs).

\section{Preparation and lethal concentration ${ }_{50}\left(\mathrm{Lc}_{50}\right)$ of Vibrio harveyi}

The Koch Postulate was conducted towards Vibrio harveyi to increase its virulence using injection method to a $5 \mathrm{~g}$ of Pacific white shrimp on the $3^{\text {rd }}$ abdomen. Vibrio harveyi then reisolated by streaking the inoculation loop on the hepatopancreas and intestine of the shrimp, then streaked it to culture the bacteria on sea water complete agar and incubated for 24 hours in 28 $30^{\circ} \mathrm{C}$. The determination of lethal concentration $\left(\mathrm{Lc}_{50}\right)$ was managed using serial dilution, i.e. $10^{7}$ $\mathrm{CFU} / \mathrm{mL}, 10^{6} \mathrm{CFU} / \mathrm{mL}, 10^{5} \mathrm{CFU} / \mathrm{mL}$, and $10^{4}$ $\mathrm{CFU} / \mathrm{mL}$. It was done for 7 days. The $10^{7} \mathrm{CFU} /$ $\mathrm{mL}$ was got as the $\mathrm{Lc}_{50}$ for the resistance test.

\section{Container preparation and resistance test}

The experimental shrimp was reared in the offshore floating net cage. The floating net cage sized in $3 \times 3 \mathrm{~m}^{2}$. Inside the floating net cage, smaller net cage sized in $1 \times 1 \times 2 \mathrm{~m}^{3}$ was placed.
Post larvae 10 (average weight $0.014 \pm 0.01 \mathrm{~g}$ and average length $0.8 \pm 0.01 \mathrm{~cm}$ ) was adapted for a day after stocked in the floating net cage (stocking density: $1000 \mathrm{ind} / \mathrm{m}^{3}$ ). The experimental shrimp was reared for 30 days. The feeding method was at satiation with feeding frequency 4 times a day $(06.00,10.00,14.00$, and 18.00)

The resistance test was conducted on PL44 (average weight : $0.48 \pm 0.07 \mathrm{~g}$, average length : $4.82 \pm 0.65 \mathrm{~cm}$ ) with stocking density $30 \mathrm{ind} /$ aquarium. It was managed in laboratory scale in the Fish Health Laboratory. The size of the aquarium was $30 \times 20 \times 20 \mathrm{~cm}^{3}$. The concentration of $V$. harveyi was $10^{7} \mathrm{CFU} / \mathrm{mL}$ (Lcso result) with ratio $1: 9(100 \mathrm{~mL}$ of bacteria : $900 \mathrm{~mL}$ of sea water). The resistance test was conducted for 7 days. During the test, the shrimp was fed using at satiation feeding method and 4 times a day feeding frequency $(07.00,11.00,15.00$, and 19.00). The immune response and stress observation was done before resistance test $(\mathrm{H} 0), 1^{\text {st }}$ day $(\mathrm{H} 1), 4^{\text {th }}$ day (H4), and $7^{\text {th }}(\mathrm{H} 7)$.

\section{The experimental parameter}

Antibacteria activity

The antibacterial testing or inhibition zone was managed to detect the ability of active compound Nodulisporium KT29 in inhibiting $V$. harveyi. The inhibition zone was tested using sea water complete agar containing $150 \mu \mathrm{L}$ of $V$. harveyi. The dosage of each treatments was $20 \mu \mathrm{L}$.

\section{Resistence of Litopenaeus vannamei}

The resistance or survival of the tested Litopenaeus vannamei was calculated based on equation below (Daniels et al., 2010). The observation of was done for seven days:

$$
\operatorname{RS}(\%)=\frac{\mathrm{Fn}}{\mathrm{In}} \times 100
$$

Note :

RS = resistence $(\%)$

Fn = final population

In $=$ initial population

The immune response of $L$. vannamei towards $V$. harveyi

The observation of immune response was conducted before infected (H0), day 1 (H1), day 4 (H4), and day 7 (H7). The immune response parameters were phenoloxidase activity (PO) (Liu \& Chen, 2004) and respiratory burst 
(RB) (Cheng et al., 2004). The phenoloxidase activity was measured through dopachrome forming data documentation which resulted by dihydroxyphenylalanine (L-DOPA). The experimental L. vannamei was crushed and the crustasea anticoagulant was added (1:2). The crushed shrimp was sentifuged for 10 minutes in $3,500 \mathrm{rpm}$. The natant substance was collected then rinsed using $1 \mathrm{~mL}$ of cacodylate-citrate buffer (sodium cacodylate $0.01 \mathrm{M}$, sodiumchloride $0.45 \mathrm{M}$, and trisodium citrate $0.10 \mathrm{M}, \mathrm{pH} 7.0$ ). Furthermore, it was sentrifuged again using the identical speed and period, then the supernatant was dismissed. A $200 \mu \mathrm{L}$ cacodylate buffer (sodium cacodylate $0.01 \mathrm{M}$, sodium chloride 0.45 $\mathrm{M}$, calsium chloride $0.01 \mathrm{M}$, and magnesium chloride $0.26 \mathrm{M}, \mathrm{pH} 7.0$ ) was added and afterward a $100 \mu \mathrm{L}$ was discarded. The $100 \mu \mathrm{L}$ of cell suspension was incubated with $50 \mu \mathrm{L}$ of trypsin ( $1 \mathrm{mg} / \mathrm{mL}$ cacodylate buffer) as an activator for 10 minutes, then added by $50 \mu \mathrm{L}$ of L-DOPA (3 $\mathrm{mg} / \mathrm{mL}$ of cacodylate buffer), incubated again for 5 minutes, and as many of $800 \mu \mathrm{L}$ of was added cacodylate buffer. As many of $200 \mu \mathrm{L}$ of the result was collected in a microplate reader and measured its optical density using $490 \mathrm{~nm}$ of wavelength.

The RB activity was measured based on the nitro blue tetrazolium (NBT) reduction as superoxide anion $\left(\mathrm{O}_{2}\right)^{-}$measurement. The experimental L. vannamei was crushed and the crustasea anticoagulant was added (1:2). As many of $300 \mu \mathrm{L}$ of the substance was collected and incubated for 30 minutes in room temperature. Moreover, it was sentrifuged for 20 minutes in $3,500 \mathrm{rpm}$. The natant layer was then added by a $100 \mu \mathrm{L} 0.3 \%$ NBT (1 capsule was dissolved in 3 $\mathrm{mL}$ of PBS) and incubated in room temperature for 1 hour. The mixture was then sentrifuged over for 10 minutes in $3,000 \mathrm{rpm}$. The supernatant layer was discarded and added $100 \mu \mathrm{L}$ of methanol absolute. Moreover, it was sentrifuged again for 10 minutes in $3,000 \mathrm{rpm}$ and the supernatant was discarded. The natant layer was rinsed twice using methanol $70 \%$, then it was added by 120 $\mu \mathrm{L}$ of potassium hydroxide $(\mathrm{KOH} 2 \mathrm{M})$ and 140 $\mu \mathrm{L}$ of DMSO (dimethyl sulfoxide). The result was collected as many of $200 \mu \mathrm{L}$ into the microplate reader and it was measured its optical density (OD) in $630 \mathrm{~nm}$ of wavelength.

\section{The stress response caused by $V$. harveyi}

The observation of stress response was conducted before infection (H0), day 1 (H1), and day 7 (H7) post infection of Vibrio harveyi. The stress response was measured through the hemolymph glucose content. The analysis of hemolymph glucose was managed using glucose liquicolor kit through CHOD-PAP (enzyme colometric test for glucose method with deproteinization) method. As many of $100 \mu \mathrm{L}$ of the hemolymph was collected and added $200 \mu \mathrm{L}$ of crustacean anticoagulant (1:2) and sentrifuged for 20 minutes in $6,000 \mathrm{rpm}$. The supernatant was collected and moved to the other microtubeto be analysed. The hemolymph glucose was calculated using the following equation :

\section{$\mathrm{GH}=\mathrm{AbsSt} / \mathrm{AbsSp} \times \mathrm{GST}$}

Note:

$\mathrm{GH}=$ hemolymph glucose concentration $(\mathrm{mg} / \mathrm{mL})$

AbsSp = sample absorbance

$\mathrm{AbsSt}=$ standard absorbance

GST = concentration of standard glucose $(\mathrm{mg} /$ dL)

\section{Data analysis}

The study used completed randomized design consisted of 5 treatments and 3 replications. The quatitative parameter (inhibition zone, immune responses (PO and $\mathrm{RB}$ ), and stress responses) was tabulated using Ms. Excel and SPSS. A significant difference was analysed uaing Duncan posthoc test in confidence level of $95 \%$. Meanwhile, clinical symtoms were analysed descriptively.

\section{RESULTS AND DISCUSSIONS}

\section{Results}

Antibacterial activity

The result of inhibition zone (in vitro) shows the Nodulisporium sp. KT29 was able to increase the inhibition zone reached up to $9.3-13 \mathrm{~mm}$ with the best treatment was $\mathrm{NM}$ and $\mathrm{NH}(13 \pm 2.6 \mathrm{~mm}$ and $12 \pm 1.0 \mathrm{~mm}$, respectively). The inhibition zone of each treatment is shown below in Table 1 .

\section{The resistance of Litopenaeus vannamei}

The result of this study presented that Nodulisporium sp. KT29 supplementation in the tested feed for 30 days was able to boost the resistance of the tested shrimp infected by $V$. harveyi. The most excellent result was presented by NM treatment $(72 \pm 2.5 \%)$ which was significantly different with the other treatments 
Table 1. Antibacterial activity of Nodulisporium sp. KT29

\begin{tabular}{ccc}
\hline Treatment & Dosage $(\mu \mathrm{L})$ & Diameter of inhibition zone $(\mathrm{mm})$ \\
\hline Chloramphenicol $(+)$ & 20 & $9.3 \pm 0.6^{\mathrm{b}}$ \\
EtOAc $(-)$ & 20 & $0.0 \pm 0.0^{\mathrm{a}}$ \\
NT & 20 & $9.3 \pm 1.1^{\mathrm{b}}$ \\
NM & 20 & $13.0 \pm 2.6^{\mathrm{c}}$ \\
NH & 20 & $12.0 \pm 1.0^{\mathrm{c}}$ \\
\hline
\end{tabular}

Note : Antibacterial activity of Nodulisporium sp. KT29 in dosage $20 \mu$ L. Treatments: chloramphenicol (positive control), EtOAc (negative control), NT (Nodulisporium sp. KT29 without V. harveyi induction), NM (Nodulisporium sp. KT29 with $5 \%$ of $V$. harveyi dead cell induction), and NH (Nodulisporium sp. KT29 with 5\% of V. harveyi live cell induction). Different superscript in the same row indicates significant difference $(\mathrm{P}<0.05)$.

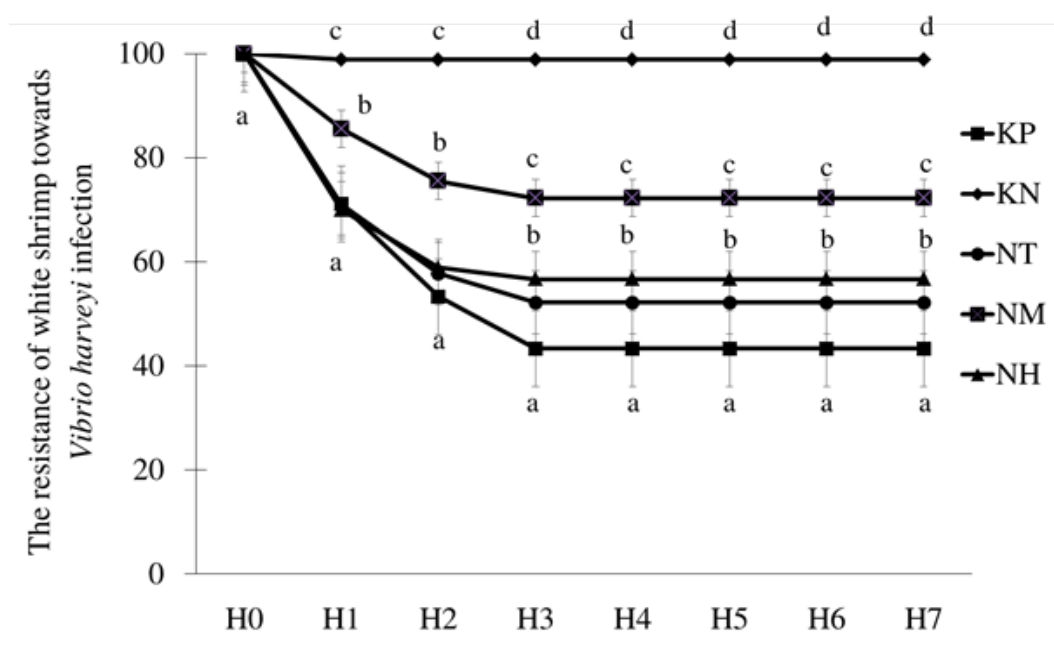

Figure 1. Mortality phase of Pacific white shrimp towards $V$. harveyi infection for 7 days. The average weight and length were $0.48 \pm 0.07 \mathrm{~g}$ and $4.82 \pm 0.65 \mathrm{~cm}$, respectively. KP (positive control), KN (negative control), NT (Nodulisporium sp. KT29 without $V$. harveyi induction), NM (Nodulisporium sp. KT29 with 5\% of V. harveyi dead cell induction), and NH (Nodulisporium sp. KT29 with 5\% of V. harveyi live cell induction). Different superscript indicates significant difference $(\mathrm{P}<0.05)$.

$(\mathrm{P}<0.05)$, except $\mathrm{NH}(56.7 \pm 3.3 \%)$ and $\mathrm{NT}$ $(52.2 \pm 1.9 \%)$ treatment. According to the result, mortality happened on the first day (H1) until the fourth day (H4) post infection. The pattern of the resistance of Pacific white shrimp is shown below in Figure 1.

\section{Phenoloxidase (PO)}

The result of phenoloxidase (PO) showed that Po activity pre infection (H0) was relatively stable amongst treatments. On the first day (H1), PO activity increased, then decreased on the $4^{\text {th }}$ and $7^{\text {th }}$ day in the NM treatment. The PO activity is presented in Figure 2A.

\section{Respiratory burst (RB)}

Supplementation Nodulisporium sp. KT29 in the feed was able to rise the respiratory burst (RB). The RB activity rose on the first day (H1) post infection with the best result was shown by $\mathrm{NM}$ treatment $(\mathrm{P}<0.05)$. RB activity in the $\mathrm{NM}$ treatment decreased on the $4^{\text {th }}$ and $7^{\text {th }}$ day. The graph of RB activity was presented below in Figure 2B.

\section{Hemolymph glucose}

The hemolymph glucose before $V$. harveyi infection was considerably stable amongst treatment. On the first day, the NT, NM, and NH presented lower level of hemolymph glucose than KP treatment. The identical condition was also found on the seventh day $(\mathrm{H} 7)(\mathrm{P}<0.05)$. The result of hemolymph glucose is decribed in Figure 3.

\section{Clinical symtomps of L. vannamei}

The clinical symtomps of of $L$. vannamei caused by $V$. harveyi infection showed redness on the hepatopancreas, muscles and body was whitish. On the contrary, the healthy shrimp looked dark and the hepatopancreas was in dark color as well. 

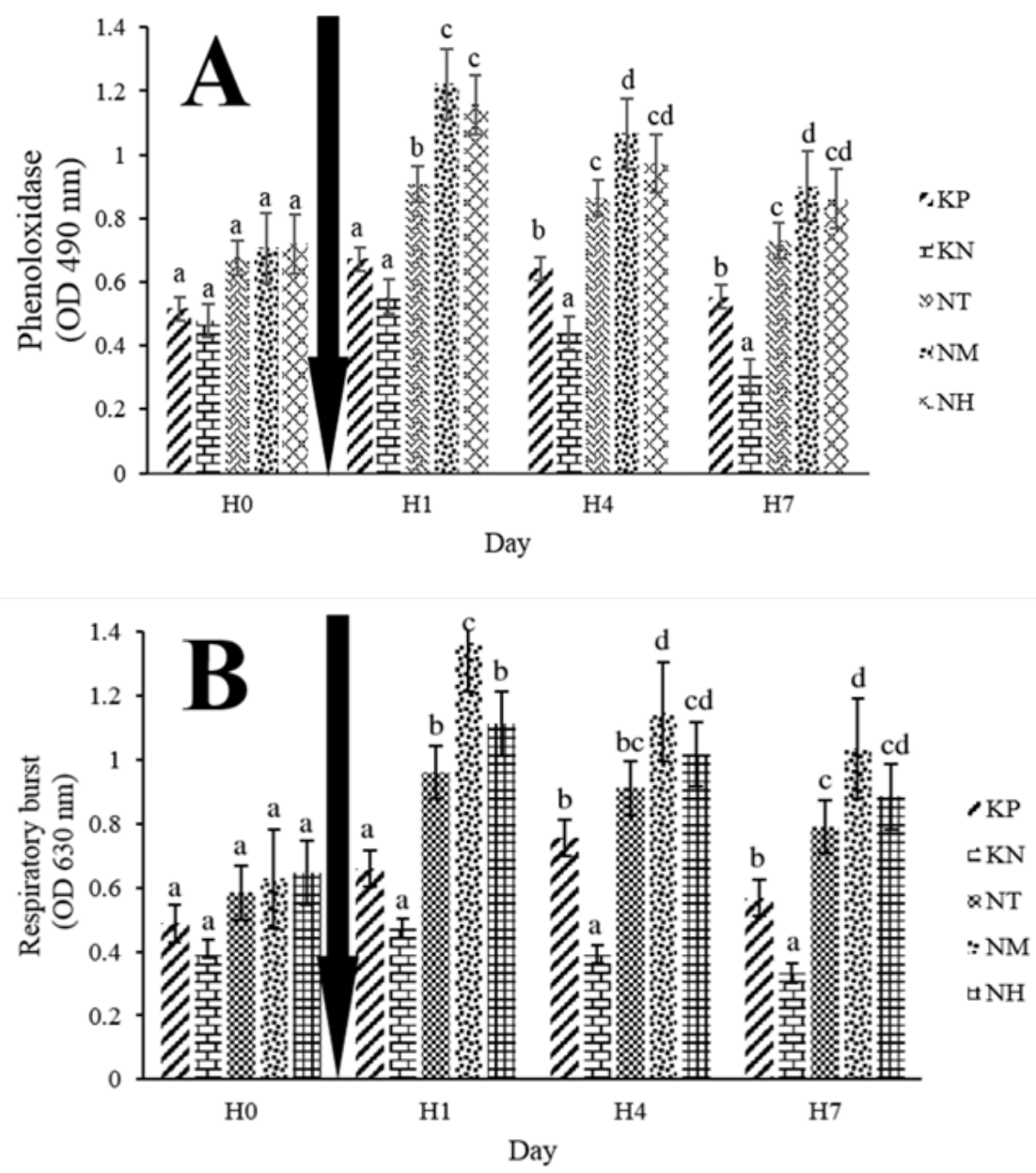

Figure 2. The activity of immune response (phenoloxydase and respiratory burst) of L. vannamei (average \pm SE) after infected by $V$. harveyi. The observation was conducted before resistance test (H0), challenged test ( $\downarrow$ ), first day of resistance test $(\mathrm{H} 1)$, fourth day $(\mathrm{H} 4)$ and seventh day $(\mathrm{H} 7)$ of resistance test. Different superscript indicates significant different $(\mathrm{P}<0.05)$ amongst treatment.

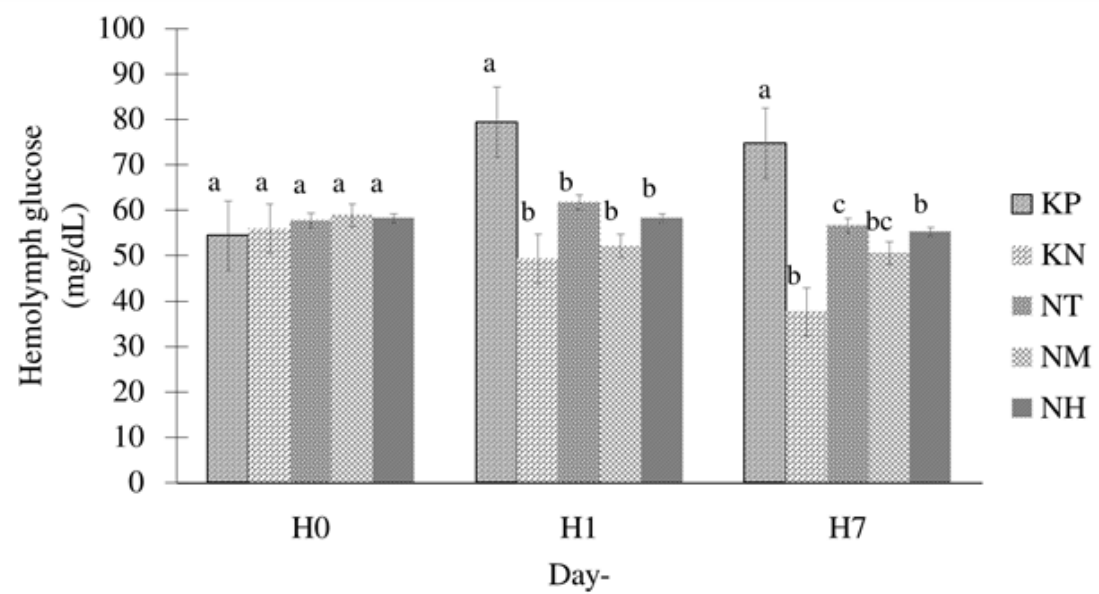

Figure 3. Hemolymph glucose of $L$. vannamei (average \pm SE). The measurement was conducted before resistance test (H0), challenged test $(\downarrow)$, day 1 of resistance test, and day 7 of resistance test. KP (positive control), KN (negative control), NT (Nodulisporium sp. KT29 without $V$. harveyi induction), NM (Nodulisporium sp. KT29 with $5 \%$ of $V$. harveyi dead cell induction), and NH (Nodulisporium sp. KT29 with $5 \%$ of $V$. harveyi live cell induction). Different superscript indicates significant difference $(\mathrm{P}<0.05)$. 


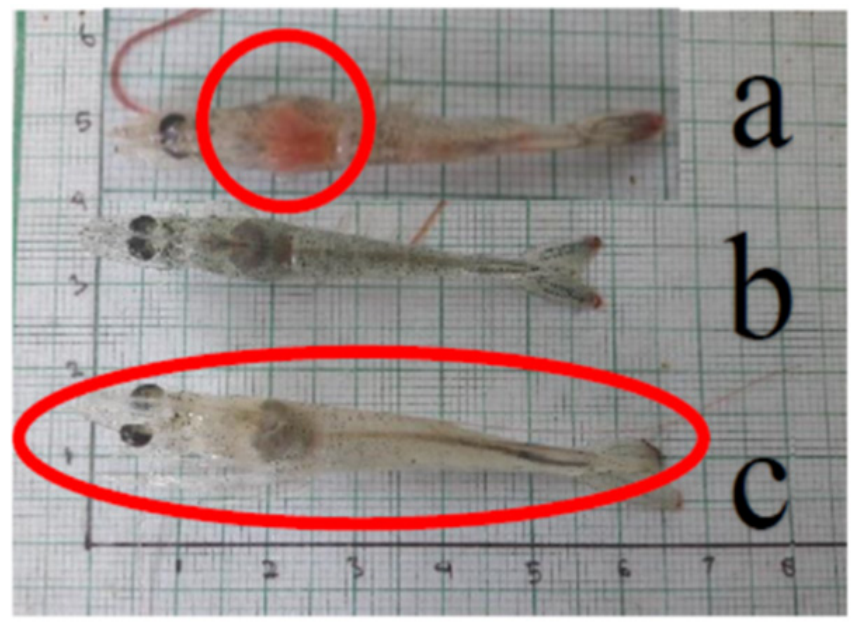

Figure 4. Clinical symptoms of L. vannamei. The a and c letter is infected shrimp, while b is healthy shrimp.

\section{Discussion}

The application of Nodulisporium sp. KT29 resulted in higher result of inhibition zone (Table 1). Bansemir et al. (2006) mentioned that inhibition zone is divided into 2 different kinds, low level (1-8 mm) and high level (8-15 $\mathrm{mm})$. The antibacterial activity is related to saponin compound which inhibit pathogenic bacteria growth. The mechanism are antagonistic activity towards pathogenic bacteria, take over the nutrition, breakdown the cell wall, and competition of area and nutrition (Schubert et al., 2008).

The active compound of Nodulisporium sp. KT29 which inducted $V$. harveyi is closely linked to antibacterial activity. The NM treatment was considered to have higher level of saponin, thus leaded to a better result in inhibition zone. The antibacterial activity holds the bactericidal mechanism which is able to destruct and kill the pathogenic bacteria. The increase of the active compound along with dead cell induction is in line with Tarman et al. (2011) mentioned that Mycellium sterium which inducted 5\% of Staphylococcus aureus (inactive colony) increased the active compound Nodulisporiusm sp. KT29. The induction method was alienated because of the competition in nutrition and environment. The other methods to rise the secondary metabolite of fungi were mutualism, neutralism, and antagonism (Cooke \& Whipps, 1993).

The administration of Nodulisporium sp. KT29 improved the resistance of $L$. vannamei towards Vibrio harveyi with the best result was NM treatment (Figure 1). The contrast in shrimp resistance amongst treatment was caused by different active compound. It could be explained by the high level of saponin and $\beta$-glucan as antibacterial compounds in the NM treatment. Saponin played as antibacterial in the organism by attaching the cell permeability membrane towards pathogenic bacteria (Couto et al., 2014). Meanwhile, $\beta$-glucan is a polysaccharides bond through $\beta$ - $(1,3)$ and glucoside $\beta$ - $(1,6)$ which commonly found in the bacteria and fungi cell wall (Bai et al., 2010). The $\beta$-glucan plays role in enhancing Penaeus lasticulatus (Hai \& Fotedar, 2009), Cherax tenuimanus (Sang \& Fotedar, 2010), and Litopenaeus vannamei (Bai et al. 2010; Chen et al., 2016) growth and immune system.

Morphological changes in the Figure 4 consisted of redness on the hepatopancreas, muscles and body became whiter, anorexia, and slow movement. Direct physical contact between shrimp and the $V$. harveyi causes a direct access for the $V$. harveyi to the digestive tract of the shrimp which causes redness on the hepatopancreas (Yeh \& Chen, 2009; Widanarni et al., 2012). On the other hand, a healty shrimp has darker color, active movement, and higher appatite. It indicated that Nodulisporium sp. KT29 supplementation boosted the immune system using active compound, such as saponin and $\beta$-glucan. The $\beta$-glucan is able to induce nonspecific immune system by enhancing lysozyme activity in both fish and shrimp (Paulsen et al., 2001; Saputra et al., 2016).

Litopenaeus vannamei is categorized as crustacean which has adaptive non specific immune system and innate immune response towards bacteria (Sang et al., 2011). The non- 
specific immune system is able to induct bacteria membrane cell, $\beta$-glucan, lypopolisaccharides, and peptidoglicant. About the pattern recognition protei, $\beta$-1.3-glucan binds protein (BGBP), LPS and protein bind $\beta$-1.3-glucan (LGBP). This activity activates serine proteases, which is proPO activating factor (PPA), then it is converted proPO into PO (phenoloxydase) through phagocytosis activity (Li \& Xiang 2013; Amparyup et al., 2013; Chaosomboon et al., 2016).

Phenoloxydase (PO) plays role as humoral immune response in crustacean and it is also known as non-specific extracellular immune system mechanism to prevent any infection caused by pathogenic bacteria. Hemocyte takes part in PO mechanism by blocking harmfull compound getting into the shrimp (Li \& Xiang, 2013; Amparyup et al., 2013). The PO activity in the NM activity showed higher increase compared to the other treatments (Figure 3A). The result showed that $\beta$-glucan takes essential part in PO activity in inducing the immune system by granular cell to capture unusual compound which invades the shrimp. The mechanism consist of proPO transformation into $\mathrm{PO}$ and inactive serine protease (proppa) into serine protease (ppa) which is activated by $\beta$-glucan and peptidoglicant to catalize monophenol and phenol oxidation in producing quinones. The quinones act as encapsulation and melanisation towards unfamiliar compounds ( $\mathrm{Li} \&$ Xiang, 2013; Amparyup et al., 2013). The PO activity is also known as unknown substances detector in humoral non-specific immune system (Li \& Xiang, 2013; Hauton, 2012). The increase of PO activity demonstrated that immunostimulant administration was able to induce the resistance and immune system of Litopenaeus vannamei towards $V$. harveyi infection (Zubaidah et al., 2015; Wahjunigrum et al., 2016).

Respiratory burst is a cellular immune response and intracellular defense in the nonspecific immune system with phagocytosis activity towards umfamiliar compound (Mai \& Wang, 2010; Hauton, 2012). The RB in the NM treatment described higher increase compared to the other treatment (Figure 2B). The result indicated that $\beta$-glucan as the active compound was able to boost the phagocytosis in inducing immune system by hyaline phagocyte cell in the phatogen debris to produce reactive oxygen mechanism (ROI). The phagocytosis activity involves the superoxide anion (dependent oxygen mechanisms) degradative enzyme releasing and the production of ROI which also known as respiratory burst (Mai \& Wang, 2010; Hauton, 2012). The mechanism of phagocytosis activity are attachment (direct contact) and ingestion of unfamiliar compound that will form digestive vacuole called phagosome. Phagosome and lysosome (hyaline phagocytes) merge and form phagolysosome which later will be destructed by unfamiliar object in the cell through ingestion process (dependent oxygen mechanism) and produce ROI. The ROI activity takes part in coordinating cortisol hormone towards glucose activity caused by the biological factor as the environment adjustment indicator (Chen et al., 2015).

The increase level of $\mathrm{RB}$ was considered as beneficial result. It is related to the shrimp immunity towards pathogen infection. However, an excessive increase level of RB is regarded as an unfortunate condition for the host (Mai \& Wang, 2010). The other studies also reported the beneficial factor of the immunostimulant to several different species, such as Cyprinus carpio (Lin et al., 2012), common carp (Djauhari et al., 2016), and Pangasianodon hypophthalmus (Tamamdusturi et al., 2016). Meanwhile, the decrease of immune response indicated recovery cell against $V$. harveyi. The later statement is supported by Huang et al. (2013) who stated that a low level of immune response is a recovery indicator of the organism.

Hemolymph glucose (GH) is a secondary stress indicator towards physiological activity and immune system indicator against the phatogen infection on shrimp and fish (Bulfon et al., 2013). The NM treatment ( $20 \mathrm{~mL})$ was capable to minimize glucose content compared with the positive control (KP) on the post infection (Figure $3)$. The polyphenol active compound which stored in Nodulisporium sp. KT29 carries out the decreasing of hemolymph glucose post-infection of $V$. harveyi. Polyphonel acts as antioxidant defense of the shrimp and cell protection against free-radical caused by oxidative stress (Wang $e t$ al., 2015). Crustacean hyperglycemic hormone $(\mathrm{CHH})$ is responsible for hemolymph activity in crustaceans and physiological behaviour (Chen et al., 2014). Stress condition triggers the hypothalamus to secrete $\mathrm{CHH}$ which will lead to inhibit insulin production (Chung et al., 2010). Glucose mechanism occurs through 
glicogenolysis. Glicogenolysis is biochemical breakdown of glucogen to glucose during stress condition and low level of insulin in neutralizing glucose content as stress response (Zhou et al., 2011).

\section{CONCLUSION}

Vibriosis control in L. vannamei using Nodulisporium sp. KT29 supplementation is considerably potential to increase the resistance and immune system. The most stand out result is presented by the NM treatment (induction of Vibrio harveyi dead cell and dosage $20 \mathrm{~mL} / \mathrm{kg}$ feed).

\section{ACKNOWLEDGEMENT}

We would like to express gratitude to LPPMIPB, the Ministry of Research, Technology, and Higher Education of Indonesia through research project under the name of Dr. Dinamella Wahjuningrum with contract number : 079/ SP2H/LT/DPRM/II/2016, and sea farming site in Semak Daun, Kepulauan Seribu, Jakarta under PKSPL IPB that has been facilitated floating cage utilization during the research.

\section{REFERENCE}

Amparyup P, Charoensapsri W, Tassanakajon A. 2013. Prophenoloxidase system and its role in shrimp immune responses against major pathogens. Fish and Shellfish Immunology 34: 990-1001.

Bai N, Zhang W, Mai K, Wang X, Xu W, Ma H. 2010. Effect of discontinuous aministration of $\beta$-glucan and glycyrrhizin on the growth and immunity of white shrimp Litopenaeus vannamei. Aquaculture 306: 218-224.

Bansemir A, Blume M, Schroder S, Lindequist U. 2006. Screening of cultivated seaweeds for antibacterial activity against fish pathogenic bacteria. Aquaculture 252: 79-84.

Bulfon C, Volpatti D, Galeotti M. 2013. Current research on the use of plant-derived products in farmed fish [review]. Aquaculture Research 46: 1-39.

Chaosomboon A, Benjaporn P, Onnicha R, Phanthipha R, Prapaporn U. 2016.
Lipopolysaccharide and $\beta$-1,3-glucan-binding protein from Fenneropenaeusmerguiensis functions as a pattern recognition receptor with a broad specificity for diverse pathogens in the defense against microorganisms. Developmental and Comparative Immunology 67: 434-444.

Chen Y, Chen W, Cheng W. 2014. The second type of transglutaminase regulates immune and stress responses in white shrimp, Litopenaeus vannamei. Fish and Shellfish Immunology 37: 30-37.

Chen YY, Chen JC, Lin YC, Yeh ST, Huang CL. 2015. White shrimp Litopenaeus vannamei that have received gracilaria tenuistipitata extract show early recovery of immune parameters after ammonia stressing. Marine Drugs 13: 3606-3624.

Chen YY. Jiann CC, Yi-Hsuan K. Yong CL, Yu-Hsuan C, Hong-Yi G, Chien-Lun H. 2016. Lipopolysaccharide and $\beta-1.3-$ glucan-binding protein (LGBP) bind to seaweed polysaccharides and activate the prophenoloxidase system inwhite shrimp Litopenaeus vannamei. Development and Comparative Imunology 55: 144-151.

Cheng W, Hsiao I, Hsu C, Chen J. 2004. Change in water temperature on the immune response of Taiwan abalone Haliotis diversicolor supertexta and its susceptibility to Vibrio parahaemolyticus. Fish and Shellfish Immunology 17: 235-243.

Chung JS, Zmora N, Katayama H, Tsutsui N. 2010. Crustacean hyperglycemic hormone $(\mathrm{CHH})$ neuropeptides family: Functions, titer, and binding to target tissues. General and Comparative Endocrinology 166: 447-454.

Couto A, Kortner TM, Penn M, Bakke AM, Krogdahl A, Teles O. 2014. Effects of dietary phytosterols and soy saponins on growth, feed utilisation efficiency and intestinal integrity of gilthead sea bream Sparus aurata juveniles. Aquaculture 432: 295-303.

Cooke RC, Whipps JM. 1993. Ecophysiology of Fungi. London (GB). Blackwell Sci Publish.

Daniels CL, Merrifield DL, Boothroyd DP, Davies SJ, Factor JR, Arnold KE. 2010. Effect of dietary Bacillus spp. and mannan oligosaccharides (MOS) on European lobster Homarus gammarus L. larvae growth 
performance, gut morphology and gut microbiota. Aquaculture 304: 49-57.

Defoirdt T, Sorgeloos P, Bossier P. 2011. Alternatives to antibiotics for the control of bacterial disease in aquaculture. Current Opinion in Microbiology 14: 251-258.

Djauhari R, Widanarni, Sukenda, Suprayudi MA, Junior MZ. 2016. Characterization of Bacillus sp. NP5 and its application as probiotic for common carp Cyprinus carpio. Research Journal of Microbiology 11: 101-111.

Ekasari J, Napitupulu JLF, Surawidjaja EH. 2016. Immunity and growth of freshwater prawn fed with dietary $\beta$-glucan supplementation. Jurnal Akuakultur Indonesia 15: 41-48.

Hauton C. 2012. The scope of the crustacean immune system for disease control. Journal of Invertebrate Pathology 110: 251-260.

Huang HH, Liu XL, Xiang JH, Wang P. 2013. Immune response of Litopenaeus vannamei after infection with Vibrio harveyi. Aquaculture 407: 115-120.

Li F, Xiang J. 2013. Recent advances in researches on the innate immunity of shrimp in China [review]. Developmental and Comparative Immunology 39: 11-26.

Lin S, Mao S, Guan Y, Luo L, Pan Y. 2012. Effect of dietary chitosan oligosaccharides and Bacillus coagulans on the growth innate immunity and resistance of koi Cyprinus carpio koi. Aquaculture 342-343: 36-41.

Liu CH, Chen JC. 2004. Effect of ammonia on the immune respons of white shrimp Litopenaeus vannamei and susceptibility to Vibrio alginolyticus. Fish and Shellfish Immunology 16: 321-334.

Mai W-J, Wang WN. 2010. Protection of blue shrimp Litopenaeus stylirostris against the white spot syndrome virus (WSSV) when injected with shrimp lysozyme. Fish and Shellfish Immunology 28: 727-733.

Mearns-Spragg A, Bregu M, Boyd KG, Burgess JG. 1998. Cross-species induction and enhancement of antimicrobial activity produced by epibiotic bacteria from marine algae and invertebrates after exposure to terrestrial bacteria. Journal of Applied Microbiology 27: 142-146.

Paulsen SM, Engstad RE, Robertsen B. 2001. Enhanced lysozyme production in Atlantic salmon S. salar L. macrophage treated with yeast $\beta$-glucan and bacterial lipopolysaccharide. Fish and Shellfish Immunology 11: 23-37.

Sang HM, Fotedar R. 2010. Effects of dietary $\beta-1,3$ glukan on the growth, survival, physiological, and immune response of marron, Cherax tenuimanus (Smith, 1912). Fish and Shellfish Immunology 28: 957-960.

Sang HM, Fotedar R, Filer K. 2011. Effects of dietary mannan oligosaccharide on the survival, growth, immunity and digestive enzyme activity of freshwater cryfish, Cherax destructor Clark (1936). Aquaculture Nutrition 17: 629-635.

Saputra F, Wahjuningrum D, Tarman K, Effendi I. 2016. Utilization of marine fungal Nodulisporium sp. kt29 metabolites to improve the production performance of marine culture of white shrimp. Jurnal Ilmu dan Teknologi Kelautan Tropis $8: 747-755$.

Schubert M, Siegfried F, Francis WMRS. 2008. In Vitro screening of an antagonistic Trichoderma strains against wood decay fungi. Arboricultural Journal 31: 227-248.

Sirirustananun N, Chen JC, Lin YC, Yeh ST, Liou CH, Sim SS, Chiew SL. 2011. Dietary administration of a Gracilaria tenuistipitata extract enhances the immune response and resistance against Vibrio alginolyticus and white spot syndrome virus in the white shrimp Litopenaeus vannamei. Fish and Shellfish Immunology 31: 848-855.

Tamamdusturi R, Widanarni, Yuhana M. 2016. Administration of probiotic Bacillus sp. NP5 and prebiotic mannan oligosaccharides for prevention of Aeromonas hydrophyla infection on Pangasianodon hypophthalmus. Journal of Fisheries and Aquatic Science 11: 1-10.

Tarman K, Lindequist U, Wende K, Porzel A, Arnold N, Wessjohann LA. 2011. Isolation of a new product and cytotoxic and antimicrobial activities of extracts from fungi of Indonesian marine habitats. Marine Drugs 9: 294-306.

Wahjuningrum D, Tarman K, Effendi I. 2016. Feeding duration of dietary Nodulisporium sp. KT29 to prevent the infection of Vibrio harveyi on Pacific white shrimp Litopenaeus vannamei. AACL Bioflux 6: 1265-1277.

Wang Y, Li Z, Li J, Duan YF, Niu J, Wang J, Huang Z, Lin HZ. 2015. Effects of dietary chlorogenic acid on growth performance, 
antioxidant capacity of white shrimp Litopenaeus vannamei under normal condition and combined stress of low-salinity and nitrite. Fish and Shellfish Immunology 42: 337-345.

Widanarni, Widagdo P, Wahjuningrum D. 2012. Oral application of probiotic, prebiotic, and synbiotic in Pacific white shrimp Litopenaeus vannamei challenged with Vibrio harveyi. Jurnal Akuakultur Indonesia 11: 54-63.

Yeh ST, Chen JC. 2009. White shrimp Litopenaeus vannamei that received the hot-water extract of Gracilaria teniustisitata showed earlier recovery in immunity after a Vibrio algnolyticus injection. Fish and Shellfish Immunology 26: 724-730.

Zhou M, Wang AL, Xian JA. 2011. Variation of free amino acid and carbohydrate concentrations in white shrimp Litopenaeus vannamei: Effects of continuous cold stress. Aquaculture 317: 182-186.

Zubaidah A, Munti Y, Widanarni. 2015. Encapsulated synbiotic dietary supplementation at different dosages to prevent vibriosis in white shrimp, Litopenaeus vannamei. Hayati Journal of Biosciences 22: 163-168. 